\title{
The Effect of Air Temperature on Water Temperature via Traditional and Statistical Experimental Design In Johor Bahru (Malaysia)
}

\author{
${ }^{1}$ Mohd Hamdan Ahmad, ${ }^{2}$ Malsiah Hamid, ${ }^{3}$ Mehdi Hanafi Koumleh, \\ ${ }^{4}$ Mohammadreza Askaripour Lahiji, ${ }^{5}$ Nora Roostapoor \\ 1,2,3 Department of Architecture , Faculty of Build Environment ,Universiti Teknologi Malaysia, 81310 UTM \\ Skudai, Johor, Malaysia \\ ${ }^{4}$ Department of Mathematics, Faculty of Science, Universiti Teknologi Malaysia,81310 UTM Skudai, Johor, \\ Malaysia \\ ${ }^{5}$ Department of Architecture, Islamic Azad University, Astaneh Ashrafieh Branch, Iran
}

\begin{abstract}
The temperature of water in each area is related to the variety of Natural factors in that area. Naturally, any changes in these conditions can influence the temperature of water and change it. However, some Human factors have noticeable impacts on it, too. Allegorically, all actions that can be taken during the process of producing drinking water can cause difference in temperatures of the water. This paper aims to provide some information about water temperature in Johor Bahru and compare it with the weather temperature at the same time. With this information, we can explore the humans' roles in changing water temperature.
\end{abstract}

Keywords: water temperature, area temperature, Johor Bahru (JB).

\section{Introduction}

Water temperature is largely controlled by air temperature; however, a number of other factors have an important influence on water temperature (Table 1). Due to climate changes, water temperatures are predicted to get warmer, potentially changing the types and amounts of plants and animals that live in the Credit River Watershed [1-4].

The human impacts also can change this temperature. Thermal pollution caused by human activities is one of the factors that can affect water temperature [5]. Many industries use river water in their processes. The water is treated before it is returned down the river, but it is warmer than it was before.

This study is intended to focus on the human's role in drinking water temperature and its measurement in Johor Bahru [6-7]. All information, related to this research, was directly obtained through field studies and tests performed. Water temperature was measured by measurement devices (thermometer) conventional and laser guns in 24 hours. Furthermore, the data obtained related to water temperature were compared with the data about weather temperature collected by the mythology department in Johor Bahru city (JB) in south of Malaysia simultaneously (15th April 2013). The site of the study, was the JB. Water treatment and measurement were done every hour in the site of the study. The water main tank was 2 meters deep, and it was away from the sunlight. This measurement was performed from the top vent of the tank. Other studies on this subject include [8-15].

Table1. Important factors influencing water temperature

\begin{tabular}{|l|l|}
\hline Factor & Potential impact on water temperature \\
\hline Climate & Warmer air temperatures can increase water temperatures. \\
\hline Groundwater & Groundwater input can reduce summer water temperature. \\
\hline Riparian cover & $\begin{array}{l}\text { Trees provide shad for streams and reduce maximum water } \\
\text { temperature. }\end{array}$ \\
\hline Stream morphology & $\begin{array}{l}\text { Deep and narrow streams are generally cooler than shallow and wide } \\
\text { streams. }\end{array}$ \\
\hline Land use & $\begin{array}{l}\text { Impervious cover can increase the temperature of surface runoff to } \\
\text { streams. }\end{array}$ \\
\hline
\end{tabular}

\subsection{Measurement}

\section{The case study}

There are a variety of techniques for measuring the water temperature parameter that can potentially yield different results because different elements are actually being measured. But there are some rules to be highly considered .If the timber thermometer (pic 1) is used, the thermometer must be located in the shade all 
the time, and be read as soon as possible after taking it out of water to avoid the effect of environmental temperature. While reading the temperature of water samples, avoid warming the thermometer with your hands or by the sun. Read the temperature measurements to the nearest $1 / 2$.

But for laser thermometer, this rule is not necessary because the thermometer can work in sunlight. Also some of the laser thermometers can show the temperature degree in Tenth grade.

In this research, both conventional and laser thermometers were simultaneously used. The simultaneous use of two thermometers can reduce the percentage of errors, and using the strengths of both of them, we can obtain more accurate information. In this study, ordinary timber thermometer was used with alcohol in it (Pic1), also the laser gun used in this research was thermometer Model "Digital Temperature Thermometer Laser Point - 58 1022F."(Pic 2)

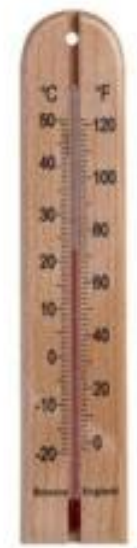

Pic 1 (Timber thermometer)

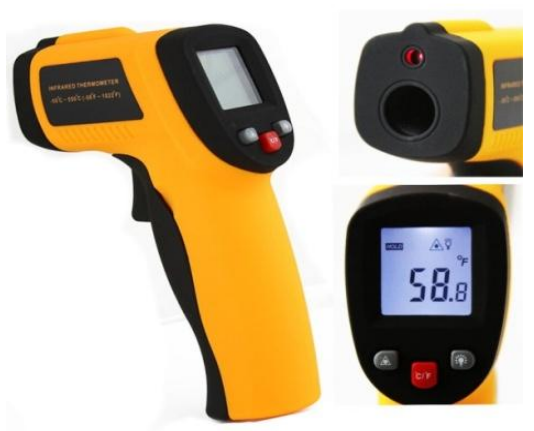

Pic2 (leaser gun thermometer)

\subsection{The study site}

We can divide the data collection into two parts. Collecting data about water and collecting data about weather. All of information about water was obtained in The Gunung Pulai water treatment plant in Johor Bahro and the data about whether were collected in the Meteorological official website. The most important of this information are information about water and air temperatures, and their measurement times.

This data obtained after 24 hours:

Table 2: The water temperature obtained by leaser thermometer

\begin{tabular}{|c|c|c|c|c|c|c|c|}
\hline Time & $\begin{array}{l}\text { WATER } \\
\text { Temp. } \\
\text { C }^{\circ}\end{array}$ & Time & $\begin{array}{l}\text { WATER } \\
\text { Temp. } \\
\text { C }^{\circ}\end{array}$ & Time & $\begin{array}{l}\text { WATER } \\
\text { Temp. } \\
\text { C }^{\circ}\end{array}$ & Time & $\begin{array}{l}\text { WATER } \\
\text { Temp. } \\
\text { C }^{\circ}\end{array}$ \\
\hline 00.00 am & 24.8 & $06.00 \mathrm{am}$ & 24.6 & $12.00 \mathrm{pm}$ & 24.4 & 06.00 pm & 25.2 \\
\hline $01.00 \mathrm{am}$ & 24.6 & $07.00 \mathrm{am}$ & 24.4 & $01.00 \mathrm{pm}$ & 24.4 & 07.00 pm & 24.8 \\
\hline 02.00 am & 24.6 & 08.00 am & 24.2 & $02.00 \mathrm{pm}$ & 24.4 & 08.00 pm & 24.8 \\
\hline 03.00 am & 24.8 & 09.00 am & 24.7 & $03.00 \mathrm{pm}$ & 24.2 & 09.00 pm & 25.2 \\
\hline $04.00 \mathrm{am}$ & 24.8 & $10.00 \mathrm{am}$ & 24.6 & 04.00 pm & 25.2 & $10.00 \mathrm{pm}$ & 25.2 \\
\hline 05.00 am & 24.6 & $11.00 \mathrm{am}$ & 24.6 & $05.00 \mathrm{pm}$ & 25.4 & $11.00 \mathrm{pm}$ & 25.0 \\
\hline
\end{tabular}

Table 3: The water temperature obtained by Timber thermometer

\begin{tabular}{|c|c|c|c|c|c|c|c|}
\hline Time & $\begin{array}{l}\text { WATER } \\
\text { Temp. } \\
\text { C }^{\circ}\end{array}$ & Time & $\begin{array}{l}\text { WATER } \\
\text { Temp. } \\
\text { C }^{\circ}\end{array}$ & Time & $\begin{array}{l}\text { WATER } \\
\text { Temp. } \\
\text { C }^{\circ}\end{array}$ & Time & $\begin{array}{l}\text { WATER } \\
\text { Temp. } \\
\text { C }^{\circ}\end{array}$ \\
\hline 00.00 am & 24.6 & 06.00 am & 24.7 & $12.00 \mathrm{pm}$ & 24.3 & $06.00 \mathrm{pm}$ & 25.0 \\
\hline $01.00 \mathrm{am}$ & 24.6 & 07.00 am & 24.4 & $01.00 \mathrm{pm}$ & 24.2 & $07.00 \mathrm{pm}$ & 25.0 \\
\hline 02.00 am & 24.6 & 08.00 am & 24.2 & $02.00 \mathrm{pm}$ & 24.2 & $08.00 \mathrm{pm}$ & 25.0 \\
\hline 03.00 am & 24.7 & 09.00 am & 24.6 & $03.00 \mathrm{pm}$ & 24.2 & $09.00 \mathrm{pm}$ & 25.0 \\
\hline 04.00 am & 24.6 & $10.00 \mathrm{am}$ & 24.5 & $04.00 \mathrm{pm}$ & 25.0 & $10.00 \mathrm{pm}$ & 24.8 \\
\hline $05.00 \mathrm{am}$ & 24.7 & $11.00 \mathrm{am}$ & 24.6 & $05.00 \mathrm{pm}$ & 25.0 & $11.00 \mathrm{pm}$ & 24.6 \\
\hline
\end{tabular}


Table 4: The data is obtained by Board Casting Office in Senai ,Johor (Malaysia)

\begin{tabular}{|c|c|c|c|c|c|c|c|}
\hline Time & Temp. $\mathrm{C}^{\circ}$ & Time & Temp. $C^{\circ}$ & Time & Temp. $C^{\circ}$ & Time & Temp. $^{\circ}$ \\
\hline 00.00 am & 25.9 & 06.00 am & 24.0 & $12.00 \mathrm{pm}$ & 28.9 & 06.00 pm & 27.9 \\
\hline $01.00 \mathrm{am}$ & 25.9 & 07.00 am & 24.9 & 01.00 pm & 28.9 & 07.00 pm & 27.9 \\
\hline $02.00 \mathrm{am}$ & 25.9 & 08.00 am & 24.9 & $02.00 \mathrm{pm}$ & 29.9 & 08.00 pm & 26.9 \\
\hline $03.00 \mathrm{am}$ & 24.9 & $09.00 \mathrm{am}$ & 25.9 & 03.00 pm & 29.9 & 09.00 pm & 26.9 \\
\hline 04.00 am & 24.9 & $10.00 \mathrm{am}$ & 26.9 & $04.00 \mathrm{pm}$ & 28.9 & $10.00 \mathrm{pm}$ & 26.9 \\
\hline $05.00 \mathrm{am}$ & 24.9 & $11.00 \mathrm{am}$ & 28.9 & $05.00 \mathrm{pm}$ & 28.9 & $11.00 \mathrm{pm}$ & 26.9 \\
\hline
\end{tabular}

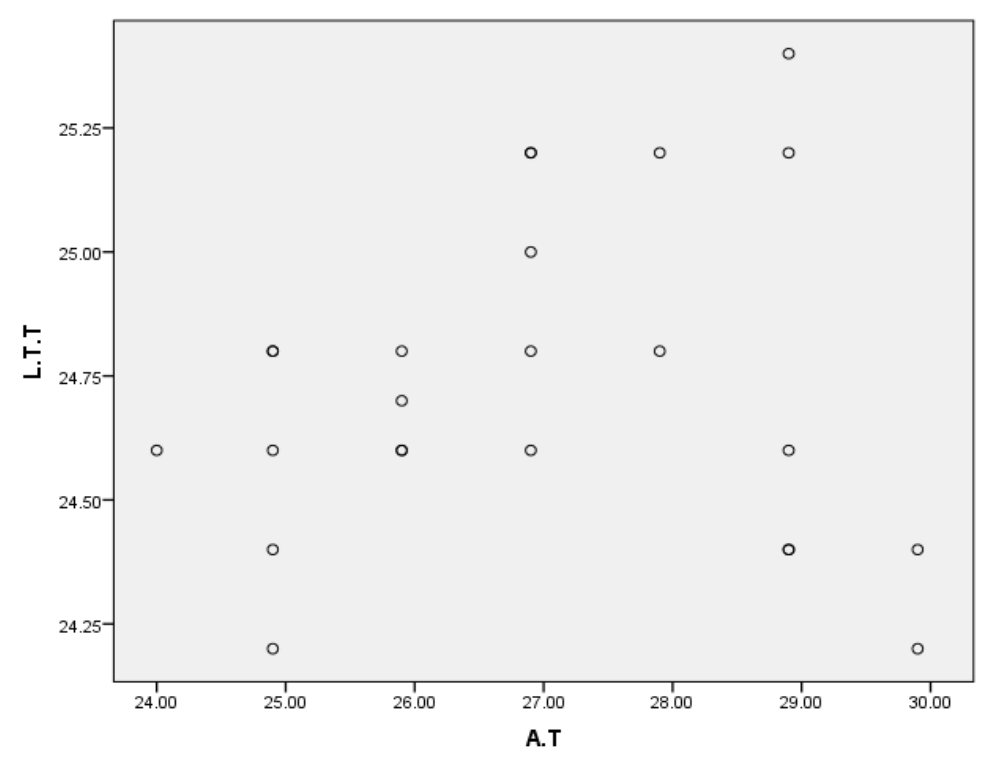

Fig 1 : L.T.T (Leaser Thermometer Temperature) \& Air Temperature

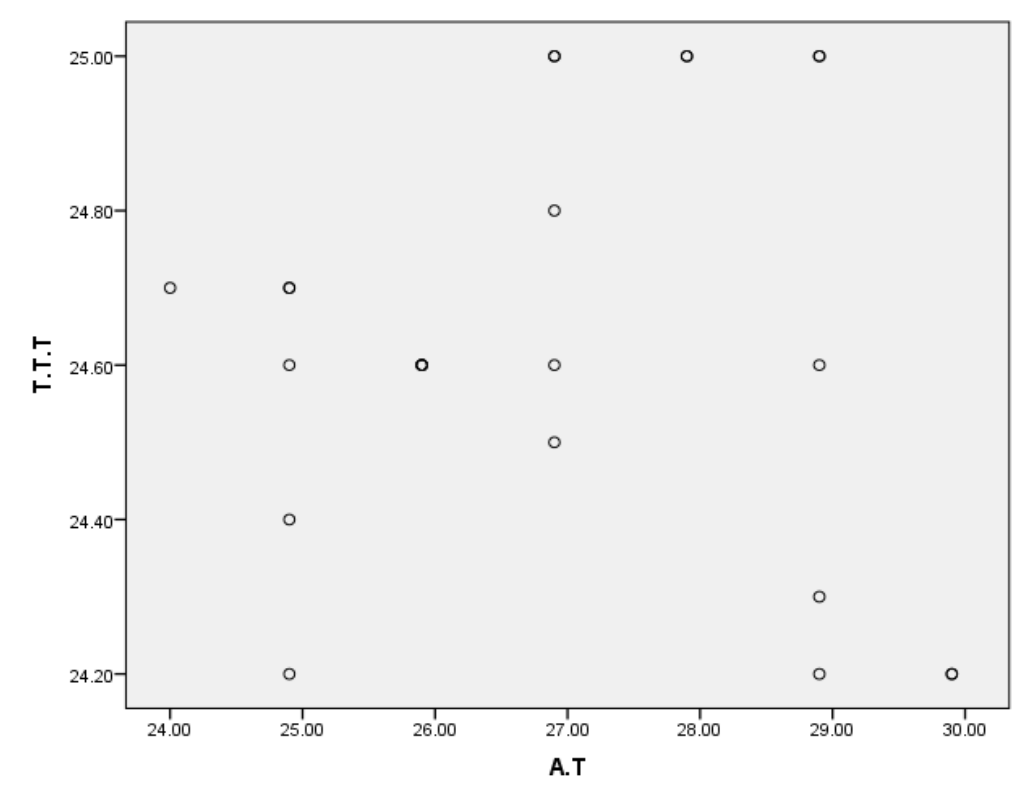

Fig 2 : T.T.T (Timber Thermometer Temp.) \& Air Temp.

According to the analysis by SPSS software as Figure 1, 2 shows, there is no correlation between the two variables. In other words, the air temperature and water temperature are totally independent completely. 
Table 5: Correlations coefficients

\begin{tabular}{|ll|l|l|}
\hline & & L.T.T & A.T \\
\hline Pearson & L.T.T & 1.000 & .071 \\
Correlation & A.T & .071 & 1.000 \\
Sig. (1-tailed) & L.T.T &. & .371 \\
& A.T & .371 &. \\
$\mathrm{~N}$ & L.T.T & 24 & 24 \\
& A.T & 24 & 24 \\
\hline
\end{tabular}

Table 6: Correlations coefficients

\begin{tabular}{|c|c|c|c|}
\hline & & T.T.T & A.T \\
\hline \multirow{2}{*}{ Pearson Correlation } & T.T.T & 1.000 & -.081 \\
\hline & A.T & -.081 & 1.000 \\
\hline \multirow{2}{*}{ Sig. (1-tailed) } & T.T.T & & .353 \\
\hline & A.T & .353 & \\
\hline \multirow{2}{*}{$\mathrm{N}$} & T.T.T & 24 & 24 \\
\hline & A.T & 24 & 24 \\
\hline
\end{tabular}

The coefficients obtained through correlation analysis also confirm that the variables are not correlated and behave separately (See Table 5, 6).

\section{Conclusion}

According to the above mentioned information, it is shown that in the studied range of the temperature, $(24.2 \mathrm{c}$ to $29.9 \mathrm{c})$ the parameters of water temperature and air temperature in Johor are independent of each other. Since some of the natural factors which can affect the water temperature (like sunlight, wind) are removed, their effect can't have any roles on the level of the water temperature. Also other human factors (like chemical changes, and all steps of the process of providing drinking water) have effects on the water temperature. Although we are sure about this independence, in other ranges, these parameters maybe show signs of dependence. Finding the answer of this question needs studies on other ranges of water and air temperature.

\section{Acknowledgments}

Mehdi and Mohammadreza wish to thank Universiti Teknologi Malaysia (UTM) .

\section{References}

[1] Cenno, K. A., Al-Ebus, M., Hirst, B., Milligan, D., \& Kratzer, T. (2005).Establishing A Temperature Discharge Relationship To Address Temperature Impairment In The Pequannock River, New Jersey For Tmdl Development. Proceedings of the Water Environment Federation, 2005(3), 702-716.

[2] Barnett, Tim, Robert Malone, William Pennell, Detlet Stammer, Bert Semtner, and Warren Washington. "The effects of climate change on water resources in the west: introduction and overview." Climatic Change 62, no. 1-3 (2004): 1-11.

[3] Proulx, Carolyn I., Michel B. Ducharme, and Glen P. Kenny. "Effect of water temperature on cooling efficiency during hyperthermia in humans." Journal of Applied Physiology 94, no. 4 (2003): 1317-1323.

[4] Twort, Alan C., Don D. Ratnayaka, and Malcolm J. Brandt. Water supply.Butterworth-Heinemann, 2000.

[5] Hammond, D., and A. R. Pryce. "Climate change impacts and water temperature." Climate change impacts and water temperature (2007).

[6] Zainal-Abideen, M., Aris, A., Yusof, F., Abdul-Majid, Z., Selamat, A., \& Omar, S. I. (2012). Optimizing the coagulation process in a drinking water treatment plant-- comparison between traditional and statistical experimental design jar tests. Water science and technology: a journal of the International Association on Water Pollution Research, 65(3), 496.

[7] Yussuf, N. M., I. Hossain, and H. Wagiran. "Natural radioactivity in drinking and mineral water in Johor Bahru (Malaysia)." Scientific Research and Essays 7, no. $9 \quad$ (2012): 1070-1075.

[8] Deas, M. L., \& Lowney, C. L. (2000). Bay Delta Modeling Forum.

[9] Taylor, K. C., Lamorey, G. W., Doyle, G. A., Alley, R. B., Grootes, P. M., Mayewski, $\quad$ P. A., ... \& Barlow, L. K. (1993). The'flickering switch' of late Pleistocene climate change. Nature, 361(6411), 432-436.

[10] Leavesley, G. H. (1994). Modeling the effects of climate change on water resources- a review. In Assessing the Impacts of Climate Change on Natural Resource Systems (pp. 159-177). Springer Netherlands.

[11] Davidson, EriC, Elizabeth Belk, and Richard D. Boone. "Soil water content and temperature as independent or confounded factors controlling soil respiration in a temperate mixed hardwood forest." Global change biology 4, no. 2 (1998): $217-227$.

[12] Moran, M. S., T. R. Clarke, Y. Inoue, and A. Vidal. "Estimating crop water deficit using the relation between surface-air temperature and spectral vegetation index." Remote sensing of environment 49, no. 3 (1994): 246-263.

[13] Kausar, R., and M. Salim. "Effect of water temperature on the growth performance and feed conversion ratio of Labeo rohita." Pakistan Vet. J 26, no. 3 (2006): 105-108.

[14] Craig, Robin Kundis. "Urban Runoff and Ocean Water Quality in Southern California: What Tools Does the Clean Water Act Provide." Chap. L. Rev. 9 (2005): 313.

[15] Wetzel, Robert G. Limnology: lake and river ecosystems. Academic press, 2001. 